\title{
Qualitative and Molecular Screening of Potential Ligninolytic Microbes from Termite (Coptotermes curvignathus) Gut
}

\section{CARLINA FREDDIE SIMOL, JOHN KEEN CHUBO*, PATRICIA JIE HUNG KING, KIAN HUAT ONG, CINDY CHEW \& KHALID NAWI}

\author{
Faculty of Agricultural Science and Forestry, Universiti Putra Malaysia Bintulu Sarawak Campus, 97008 \\ Bintulu, Sarawak, Malaysia \\ *Corresponding author: johnkeen@upm.edu.my \\ Received: 24 December 2020 \\ Accepted: 15 June 2021 \\ Published: 30 June 2021
}

\begin{abstract}
Ligninolytic microbes have great potential in converting high lignin by-products to more utilisable products by decomposing the lignin-rich agricultural and industrial wastes. Thus, the aim of this study are to screen and identify the potential ligninolytic microbes from the termite (Coptotermes curvignathus) gut. The study was conducted at Universiti Putra Malaysia Bintulu Sarawak Campus, Malaysia. Twenty-seven microbes isolated from termite gut obtained from the Microbiology Laboratory, Faculty of Agricultural Science and Forestry, were used for the ligninolytic activity screening. Media with four different ligninolytic indicator dyes (Azure B, phenol red, methylene blue, and Remazol Brilliant Blue) were streaked with microbial isolates and incubated at $37{ }^{\circ} \mathrm{C}$ for $48 \mathrm{~h}$. Out of twenty-seven microbe isolates, only three ( $\mathrm{CH} 2, \mathrm{CH} 5$, and $\mathrm{CH} 9)$ isolates showed decolourisation zone indicating the positive presence of ligninolytic activity. The 16S rRNA gene sequence data indicated the isolates are highly homologous to Bacillus spp.
\end{abstract}

Keywords: Ligninolytic enzyme, ligninolytic microbe, termite gut

Copyright: This is an open access article distributed under the terms of the CC-BY-NC-SA (Creative Commons Attribution-NonCommercial-ShareAlike 4.0 International License) which permits unrestricted use, distribution, and reproduction in any medium, for non-commercial purposes, provided the original work of the author(s) is properly cited.

\section{INTRODUCTION}

Lignin is one of the most abundant aromatic biopolymers in nature and accounts for nearly $30 \%$ in the secondary wall of plants (Chaurasia, 2019). The lignin content varies with species and generally ranges between $5 \%$ and $12 \%$ in monocotyledons, $25 \%$ and $35 \%$ in softwoods and $15 \%$ and $30 \%$ in hardwoods (Chandra et al., 2017). It is a necessary plant protection agent. Lignin is a phenolic polymer that can cause difficulty in industrial biomass processing. Lignin can be removed or modified via chemical, mechanical or enzymatic treatments. Ligninolytic enzymes are known for their roles in the degradation of various complexes and recalcitrant polymers and are highly versatile and ubiquitous in nature (Chandra \& Chowdhary, 2015; Chowdhary et al., 2016).

Commercialisation and intensification of agricultural production to meet the increasing demand of the world's population has contributed to the mounting amount of agricultural waste. Agriculture by-products, which are naturally high in lignin, are posing threats to the environment due to their low biodegradability. Besides being the byproduct of agricultural or agro-industrial activities, these ligninolytic wastes are also generated through sago industry, forestry, pulp and paper industries, and other timber-related industries. Thus, when discarded indiscriminately, these wastes may cause environmental pollution, including toxicity problem in waterways.

By-products with high lignin could be converted to useful products by degrading the lignin using bacteria. Ligninolytic enzymes produced by the bacteria are involved in the degradation of the complex and recalcitrant polymer lignin. In nature, many microbes could have ligninolytic activity, but these microbes are still largely unexplored.

Previous studies have evaluated a number of microbes, namely Bacillus spp., Citrobacter spp., Pseudomonas spp., Klebsiella pneumonia, and Serratia marcescens, that produced extracellular peroxidases which aid in lignin degradation (Mathews et al., 2014; Yadav \& Chandra, 2018). The termite gut contains different kinds of 
microbes. There are as many as 250 different species of microbes in the relatively tiny gut that help termites in degrading complex materials into different end products such as glucose and acetate, which are the primary source of energy (Wong et al., 2014). However, not all microorganisms in the termite gut help in lignin degradation. Different microbes (Bacteria, Archaea, and Eukarya) in the termite gut have different needs but share a common goal of degrading lignin and other components into different applicable products (Inagaki \& Matsuura, 2018; Kundu et al., 2019).

Microbes from the termite gut are known to be lignocellulosic enzyme producers, including Pseudomonas, Bacillus, Enterobacter, Streptomyces, and Paenibacillus (Dheeran et al., 2012; Matte'otti et al., 2012). An early study on lignin degradation by bacteria isolated from termite gut has been reported by Azizi-Shotorkhoft et al. (2016). The bacteria were able to degrade $28 \%$ of dealkalized lignin $60 \%$ to $95 \%$ of lignin dimer compounds.

Research conducted by Jalali (2014) isolated 13 lignin-degrading bacterial strains from the gut of the termite Anacanthotermes vagans. The greatest lignin-degrading activity was recorded for the Enterobacter and Klebsiella strains. Additionally, Taylor et al. (2012) isolated nine mesophilic bacterial strains from forest soil incubated in enrichment cultures containing wheat straw lignocellulose namely four Microbacterium isolates, two Micrococcus isolates, one Rhodococcus erythropolis (all Actinobacteria) and two Ochrobactrum isolates (Alphaproteobacteria). The study by Taylor et al. (2012) was the first experiment on the lignin degradation ability of Microbacterium strains and the first to report on the lignin-degrading ability of Microbacterium strains isolated from the termite gut.

Dashtban et al. (2010) reported more than 14,000 of fungal species expressing ligninolytic enzymes [laccase, lignin peroxidase $(L i P)$ and manganese peroxidase $(M n P)]$ in the environment. Most fungal species are found producing several synergistically active ligninolytic enzymes into the environment and considered contributing to the reduction of lignocellulosic waste (Taylor et al., 2012). However, limited information is available regarding the potential of isolated bacteria from the termite gut in degrading lignocellulosic materials (Azizi-Shotorkhoft et al., 2016). Therefore, this study aimed to screen and identify ligninolytic microbes from the gut of termite, Coptotermes curvignathus.

\section{MATERIALS AND METHODS}

\section{Source of Microbes}

Twenty-seven microbes were previously isolated from the gut of termite Coptotermes curvignathus were used in this study. The microbes' isolates were obtained from the collection of the Microbiology Laboratory, Department of Crop Science, Faculty of Agricultural Science and Forestry, Universiti Putra Malaysia Bintulu Sarawak Campus, Malaysia. All microbes' isolates were grown on Luria-Bertani (LB) agar at $37{ }^{\circ} \mathrm{C}$ for $48 \mathrm{~h}$. The grown microbes were subjected to the ligninolytic screening analysis.

\section{Ligninolytic Screening Analysis Using Dye Decolourisation Assay}

The procedures were as described by Husain (2006), Pangallo et al. (2007), Ang et al. (2011), and Bandounas et al. (2011). Four ligninolytic indicator dyes, namely Azure B, phenol red, methylene blue, and Remazol Brilliant Blue were used. The dyes were filtered and sterilised prior to adding them into the autoclaved media under aseptic condition. A Petri dish with LB agar 0.2 $\mathrm{g} / 100 \mathrm{~mL}$ of Azure B (Archibald 1992), $0.1 \mathrm{~g} / 100$ $\mathrm{mL}$ of phenol red, $0.2 \mathrm{~g} / 100 \mathrm{~mL}$ of methylene blue (Manji \& Ishihara 2004), and $0.4 \mathrm{~g} / 100 \mathrm{~mL}$ of Remazol Brilliant Blue (Kiiskinen et al., 2004) respectively were prepared and streaked with microbial isolates. The media were incubated at $37{ }^{\circ} \mathrm{C}$ for $48 \mathrm{~h}$. The plates without any inoculum were included as a control in this experiment. Each treatment was replicated three times. The plates were observed for the growth of the isolates and the presence of the decolourisation zones. The presence of the decolourisation zone of indicator dye was observed as it suggests the presence of ligninolytic activity. All microbes were then subjected to characterisation of the isolates via molecular analysis.

\section{DNA Extraction from Microbial Isolates}

A single colony was selected and inoculated into 2 $\mathrm{ml}$ of nutrient broth in a specimen glass bottle using an inoculating loop. The bacterial culture was incubated in a shaking incubator (WiseCube) at $37^{\circ} \mathrm{C}$ and shaken constantly at $80 \mathrm{rpm}$ for $24 \mathrm{~h}$ or longer to obtain maximum yield. High yield 
pure bacteria culture is important in determining the success rate of deoxyribonucleic acid (DNA) extraction process.

The DNA extraction was done using the DNeasy Blood and Tissue Kit from Qiagen based on the protocol provided in the kit. The bacterial pellet was suspended in $480 \mu \mathrm{L}$ of Ethylenediaminetetraacetic acid (EDTA) and $120 \mu \mathrm{L}$ of lysozyme. The mixture was incubated at $37^{\circ} \mathrm{C}$ for $30 \mathrm{~min}$. Later, $25 \mu \mathrm{L}$ of proteinase $\mathrm{K}$ and $200 \mu \mathrm{L}$ of Buffer AL (supplied in the DNeasy Blood and Tissue Kit (Qiagen) were added and mixed with the sample by vortexing. The sample was incubated at $56^{\circ} \mathrm{C}$ for $30 \mathrm{~min}$. Then, $200 \mu \mathrm{L}$ of ethanol was added, and the sample was mixed by vortexing. The mixture was transferred to a 2 $\mathrm{mL}$ collection tube and centrifuged at $8000 \mathrm{rpm}$ for $1 \mathrm{~min}$. The supernatant was discarded, and $500 \mu \mathrm{L}$ of Buffer AW1 was added to the pelletised sample. It was centrifuged again at $8000 \mathrm{rpm}$ for $1 \mathrm{~min}$. The supernatant was discarded again and $500 \mu \mathrm{L}$ of Buffer AW2 was added to the pelletised sample. The sample was then centrifuged again at 13200 rpm for 3 min to eliminate the chance of possible Buffer AW2 carryover. The spin-column of the tube was transferred to a sterilised $1.5 \mathrm{ml}$ microcentrifuge tube, and $30 \mu \mathrm{L}$ of Buffer $\mathrm{AE}$ was added to the sample. The sample was left to incubate at room temperature for $20 \mathrm{~min}$ and then centrifuged at $6000 \mathrm{rpm}$ for $1 \mathrm{~min}$ to elute.

\section{Polymerase Chain Reaction Amplification of 16S rRNA}

The Polymerase Chain Reaction (PCR) was used to amplify the bacterial DNA for preparation of DNA sequencing. In this study, the universal primers from Integrated DNA Technologies: $27 \mathrm{~F}$ primer (5'-AGA-GTT-TGA-TCM-TGG-CTC-AG-3') and 1492R primer (5'-GGT-TAC-CTT-GTT-ACG ACT T-3') were used. A master mix was prepared using the following ingredients: $2 \mu \mathrm{L}$ of $\mathrm{MgCl}_{2}, 5$ $\mu \mathrm{L}$ of $10 \mathrm{X}$ Buffer, $1 \mu \mathrm{L}$ of dNTPs, $1 \mu \mathrm{L}$ of each primer and $0.25 \mu \mathrm{L}$ of Taq DNA polymerase. DNA template and ultrapure water were added to the master mix to make a total volume of $50 \mu \mathrm{L}$ of mixture for PCR. The amplifications of PCR products were observed by running electrophoresis to verify the base pair ranges. For sequencing identification, $5 \mu \mathrm{L}$ of purified DNA, together with both forward and reverse primer were sent to First BASE Laboratories Sdn. Bhd. for DNA sequencing. Comparison was done between DNA sequence of the samples obtained from
First BASE Laboratories Sdn. Bhd. with the DNA sequences in the GeneBank database using the Basic Local Alignment Search Tools (BLAST) server (http://www.ncbi.nlm.nih.gov/blast) of the National Centre for Biotechnology Information (NCBI). Blast hits with E-value equal to 0 were taken as possible identities.

\section{RESULTS AND DISCUSSION}

The termite gut bacterial isolates were screened for their ability to decolourise the synthetic dyes which mimicking the structure of lignin. Decolourised zones (Figure 1) were observed after $48 \mathrm{~h}$ for indication of ligninolytic activity by the microbial isolate. Results in Table 1 show that the microbial isolates $\mathrm{CH} 2, \mathrm{CH} 3, \mathrm{CH} 5, \mathrm{CH} 9, \mathrm{H} 6$ and TG005 were successfully decolourised the Azure B dye with different zone clearing capacity. The result was slightly similar when tested on the methylene blue dye. Isolate $\mathrm{CH} 2, \mathrm{CH} 5, \mathrm{CH} 9, \mathrm{H} 2, \mathrm{H} 9, \mathrm{TG} 005$, TG009 and G1004 were capable of decolourising the dye, demonstrating LiP enzymes' presence (Zhou et al., 2017). The decolourisation zone was also identified in isolates $\mathrm{CH} 2, \mathrm{CH} 3, \mathrm{CH} 5, \mathrm{CH} 9$ and TG005 when the microbes were grown in the LB agar supplemented with the Remazol Brilliant Blue dye. This may suggest that the microbes showed laccase activity (Tian et al., 2020). Only three isolates $(\mathrm{CH} 2, \mathrm{CH} 5$ and $\mathrm{CH} 9)$ were able to decolourise phenol red dye indicating the production of $M n P$ enzyme that oxidises the dye and removes the original red colour of phenol (Zainith et al., 2019).

Based on the preliminary screening result, 10 microbial isolates were identified to possess at least one ligninolytic enzyme activity, which may be potential for lignin degradation. Interestingly, three microbial isolates, $\mathrm{CH} 2, \mathrm{CH} 5$ and $\mathrm{CH} 9$ showed the ability to decolourise all four synthetic dyes, thus suggesting the isolates may also produce laccase, $L i P$, and $M n P$, which are crucial to degrade lignin into simpler substrates (Lai et al., 2017). Three isolates exhibited a dominant decolourisation zone compared to the others, insinuating that the isolates have a high potential to degrade lignin better or faster than other tested microbes in this study.

The 10 potential ligninolytic microbes were further subjected to $16 \mathrm{~S}$ rDNA sequencing analysis for characterisation of the microbes. The result of the Blast against NCBI database is shown in Table 2. The result showed $100 \%$ similarity percentage 


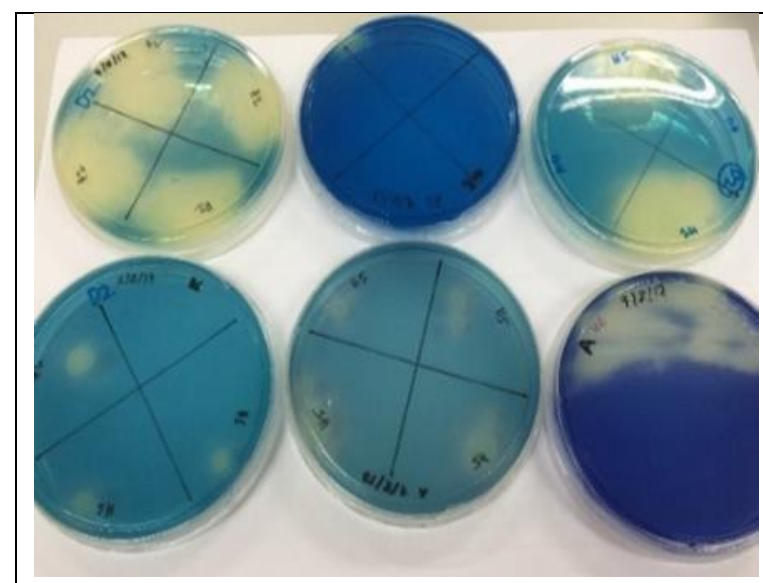

(a)

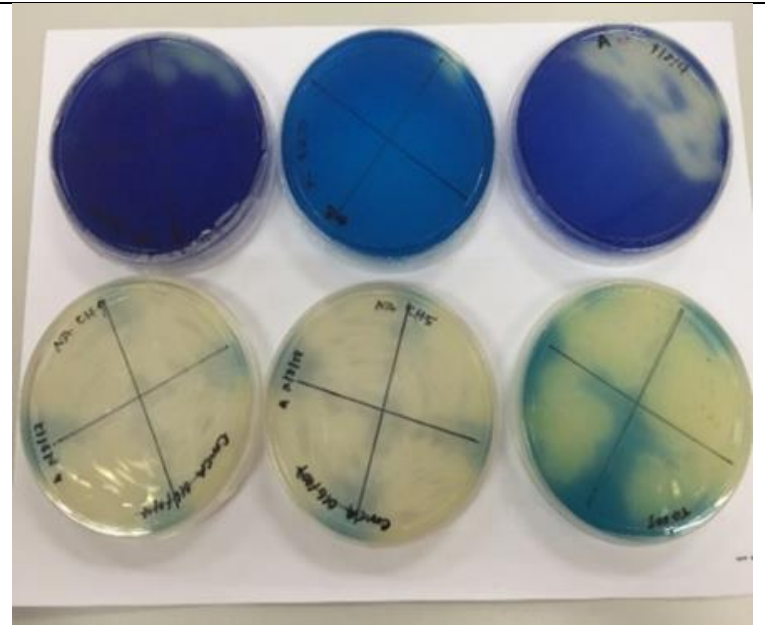

(c)

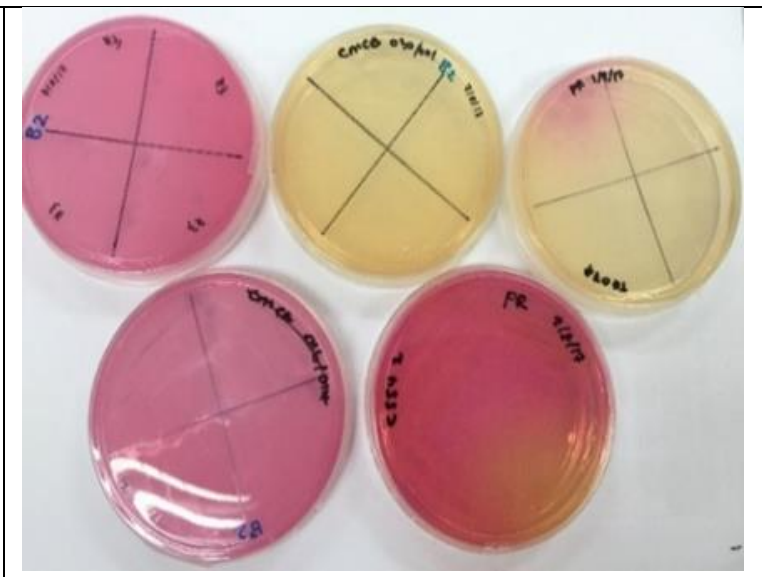

(b)

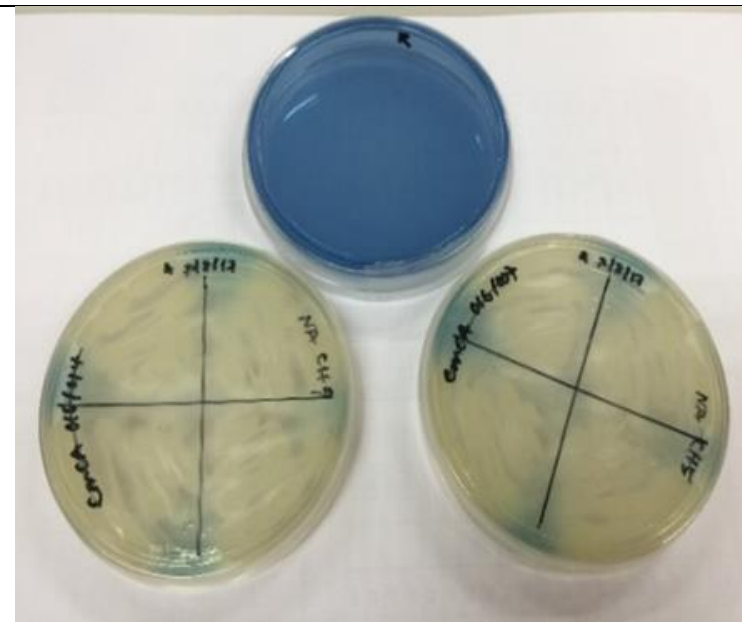

(d)

Figure 1. Clear zone around the microbial colony confirms the secretion of ligninolytic enzymes by the isolate as shown on (a) Azure B; (b) Phenol red; (c) Methylene blue; and (d) Remazol Brilliant Blue plate

for the Bacillus spp. in $\mathrm{CH} 2, \mathrm{CH} 5$ and $\mathrm{CH} 9$. While 99\% was recorded for Acinetobacter spp. in $\mathrm{CH} 3$, and the remaining isolates were unidentified.

Bacillus spp. have been reported to be the common bacteria involved in lignin decomposition process (Gonzal et al., 2016). The bacteria have been found in various sources such as soil beneath decomposing woods (Chang et al., 2014), water waste derived from pulp and paper mill (Zainith $e t$ al., 2019), rotten wood (Yang et al., 2017) and waste sludge of cow farmyard (Shah et al., 2019).

Previous initiatives of isolating lignindegrading bacteria from the termite gut have successfully characterised $B$. licheniformis and Enterobacter spp. to have strong $L i P$ activity (Zhou et al., 2017). Lai et al. (2017) further reported that Bacillus spp. are known to have the capability of producing $L i P, M n P$ and laccase enzymes thus confirming the findings of this study. Recently, Acinetobacter has also shown the ability to break down both high and molecular weight lignin (Yang et al., 2017). Acinetobacter colcoaceticus has demonstrated LiP activity (Janusz et al., 2017), and this supports the screening result of $\mathrm{CH} 3$ in this study.

Current work suggested that the $\mathrm{CH} 2, \mathrm{CH} 5$ and $\mathrm{CH} 9$ isolates may have the potential to decompose lignin due to their ability to decolourise the lignin-like synthetic dyes. However, further characterisations will be needed to confirm the species and strain of the isolates. This includes the morphology, standard biochemical tests, cellular fatty acid profile analysis, and measurement of laccase, $L i P$ and $M n P$ enzyme activities of potential ligninolytic isolates. 
Table 1. Growth of microbial isolates on lignin monomers

\begin{tabular}{|c|c|c|c|c|}
\hline \multirow{2}{*}{$\begin{array}{l}\text { (Microbes) } \\
\text { Code }\end{array}$} & \multicolumn{4}{|c|}{ Ligninolytic Indicator Dyes } \\
\hline & Azure B & Methylene blue & $\begin{array}{c}\text { Remazol Brilliant } \\
\text { Blue }\end{array}$ & Phenol red \\
\hline $\mathrm{CH} 2$ & $\sqrt{ }$ & $\sqrt{ }$ & $\sqrt{ }$ & $\sqrt{ }$ \\
\hline $\mathrm{CH} 3$ & $\sqrt{ }$ & + & $\sqrt{ }$ & + \\
\hline $\mathrm{CH} 5$ & $\sqrt{ }$ & $\sqrt{ }$ & $\sqrt{ }$ & $\sqrt{ }$ \\
\hline $\mathrm{CH} 9$ & $\sqrt{ }$ & $\sqrt{ }$ & $\sqrt{ }$ & $\sqrt{ }$ \\
\hline $\mathrm{H} 2$ & + & $\sqrt{ }$ & + & + \\
\hline $\mathrm{H} 3$ & + & + & + & + \\
\hline $\mathrm{H} 5$ & + & + & + & + \\
\hline H6 & $\sqrt{ }$ & + & + & + \\
\hline H9 & + & $\sqrt{ }$ & + & + \\
\hline CMCB030/011 & + & - & + & - \\
\hline СМCB030/013 & + & + & + & - \\
\hline CMCB030/032 & + & + & + & - \\
\hline TG005 & $\sqrt{ }$ & $\sqrt{ }$ & $\sqrt{ }$ & - \\
\hline TG009 & + & $\sqrt{ }$ & + & + \\
\hline TG015 & - & + & + & - \\
\hline TG059 & + & - & + & - \\
\hline TG071 & + & + & + & + \\
\hline TG074 & - & + & + & + \\
\hline TG085 & - & - & + & - \\
\hline TG086 & - & - & - & - \\
\hline TG091 & - & - & - & - \\
\hline TG103 & - & + & - & - \\
\hline TG104 & + & $\sqrt{ }$ & + & + \\
\hline TG105 & - & - & - & - \\
\hline TG111 & - & + & - & - \\
\hline TH114 & - & + & + & - \\
\hline TG120 & - & + & + & - \\
\hline
\end{tabular}

Note: Codes indicate the unidentified microbes isolated from terminate gut obtained from Microbiology Laboratory. Growth of microbes isolates with lignin monomer as sole carbon and energy source. $(-)$, no growth; $(+)$, growth; $(\sqrt{ })$, growth with decolourised zone. 
Table 2. Microbial identification by using 16S rRNA gene sequences

\begin{tabular}{|c|c|c|c|c|c|}
\hline $\begin{array}{l}\text { Bacterial } \\
\text { Isolate Codes }\end{array}$ & Blast Hits & $\begin{array}{l}\text { Maximum } \\
\text { Score }\end{array}$ & E Value & $\begin{array}{c}\text { Similarity } \\
\text { Percentage (\%) }\end{array}$ & $\begin{array}{l}\text { GenBank } \\
\text { Accession }\end{array}$ \\
\hline \multirow[t]{3}{*}{$\mathrm{CH} 2$} & $\begin{array}{l}\text { Bacillus toyonensis strain } \\
\text { BCT-7112 }\end{array}$ & 806 & 0.00 & 100 & NR121761 \\
\hline & Bacillus anthrasis strain SBS1 & 806 & 0.00 & 100 & NR118536 \\
\hline & Bacillus anthrasis strain SB1 & 806 & 0.00 & 100 & NR118379 \\
\hline \multirow[t]{3}{*}{ CH5 } & $\begin{array}{l}\text { Bacillus toyonensis strain } \\
\text { BCT-7112 }\end{array}$ & 1168 & 0.00 & 100 & NR121761 \\
\hline & $\begin{array}{l}\text { Bacillus cereus strain } \\
\text { ATCC } 14579\end{array}$ & 1168 & 0.00 & 100 & NR074540 \\
\hline & $\begin{array}{l}\text { Bacillus cereus strain } \\
\text { JCM } 2152\end{array}$ & 1168 & 0.00 & 100 & NR113266 \\
\hline \multirow[t]{4}{*}{ CH9 } & $\begin{array}{l}\text { Bacillus toyonensis strain } \\
\text { BCT-7112 }\end{array}$ & 1236 & 0.00 & 100 & NR121761 \\
\hline & $\begin{array}{l}\text { Bacillus cereus strain } \\
\text { JCM } 2152\end{array}$ & 1236 & 0.00 & 100 & NR113266 \\
\hline & Bacillus thuringiensis & 1236 & 0.00 & 100 & NR112780 \\
\hline & NBRC101235 & & & & \\
\hline \multirow[t]{3}{*}{$\mathrm{CH} 3$} & $\begin{array}{l}\text { Acinetobacter dispersus strain } \\
\text { ANC4150 }\end{array}$ & 1186 & 0.00 & 99 & NR148844 \\
\hline & $\begin{array}{l}\text { Acinetobacter calcoaceticus } \\
\text { strain ATCC } 23055\end{array}$ & 1175 & 0.00 & 99 & NR119357 \\
\hline & $\begin{array}{l}\text { Acinetobacter vivianii strain } \\
\text { NIPH } 2168\end{array}$ & 1173 & 0.00 & 99 & NR148847 \\
\hline $\mathrm{H} 2$ & -NIL- & -NIL- & -NIL- & -NIL- & \\
\hline H6 & -NIL- & -NIL- & -NIL- & -NIL- & \\
\hline H9 & -NIL- & -NIL- & -NIL- & -NIL- & \\
\hline TG005 & -NIL- & -NIL- & -NIL- & -NIL- & \\
\hline TG009 & -NIL- & -NIL- & -NIL- & -NIL- & \\
\hline TG104 & -NIL- & -NIL- & -NIL- & -NIL- & \\
\hline
\end{tabular}




\section{CONCLUSION}

Lignin is a complex substrate known to require a suite of oxidative enzymes and assorted small molecule co-factors for its degradation. By exploring greater diversity of organisms that can react with and metabolise lignin, we may gain new insight into lignin degradation mechanism using a wide range of microbial-derived ligninolytic enzymes. To improve the access of microbial hydrolytic enzymes to cellulose and hemicellulose for digestibility improvement, it is necessary to break lignin-carbohydrate linkages in plant cell walls.

This research found three $(\mathrm{CH} 2, \mathrm{CH} 5$, and $\mathrm{CH} 9)$ microbes isolated from the termite $(C$. curvignathus) gut that showed a positive presence of ligninolytic activity based on the decolourisation of all four lignin-like synthetic dyes (Azure B, phenol red, methylene blue and Remazol Brilliant Blue). Identification based on the 16S rRNA gene sequence further proved the three microbe isolates belonging to the genus Bacillus. Further research will be required to quantify the enzymes released by the isolates and confirm the potential of the three isolates in degrading lignin.

\section{ACKNOWLEDGEMENTS}

The authors would like to thank Universiti Putra Malaysia for the postgraduate scholarship financial support. This research was funded by Putra Grant Scheme (UPM/800-3/3/1/GP-IPB/9557602) of Universiti Putra Malaysia.

\section{REFERENCES}

Ang, T.N., Ngoh, G.C. \& Chua, A.S.M. (2011). A quantitative method for fungal ligninolytic enzyme screening studies. Asia-Pacific Journal of Chemical Engineering, 6(4): 589-595. DOI.org/10.1002/ apj.451.

Archibald, F.S. (1992). A new assay for lignin-type peroxidases employing the dye Azure B. Applied and Environmental Microbiology, 58(9): 31103116.

Azizi-Shotorkhofta, A., Mohammadabadia, T., Motamedib, H., Chajia, M. \& Fazaeli, H. (2016). Isolation and identification of termite gut symbiotic bacteria with lignocellulose-degrading potential, and their effects on the nutritive value for ruminants of some by-products. Animal Feed Science and Technology, 221(3).: 234-243. https://doi.org/10.10 16/j.anifeedsci.2016.04.016

Bandounas, L., Wierckx, N.J.P., de Winde, J.H. \& Ruijssenaars, H.J. (2011). Isolation and characterisation of novel bacterial strains exhibiting ligninolytic potential. BMC Biotechnology, 11: 94.

Chandra, R. \& Chowdhary, P. (2015). Properties of bacterial laccases and their application in bioremediation of industrial wastes. Environmental Sciences: Processes and Impacts, 17(2): 326-342.

Chandra, R., Kumar, V. \& Yadav, S. (2017). Extremophilic ligninolytic enzymes. In Sani, R.K., \& Krishnaraj, R.N. (eds.) Extremophilic Enzymatic Processing of Lignocellulosic Feedstocks to Bioenergy. Cham, Switzerland, Springer International Publishing. Pp. 115-154.

Chang, Y.C., Choi, D., Takamizawa, K. \& Kikuchi, S. (2014). Isolation of Bacillus sp. strains capable of decomposing alkali lignin and their application in combination with lactic acid bacteria for enhancing cellulase performance. Bioresource Technology, 152: 429-436.

Chaurasia, B. (2019). Biological pretreatment of lignocellulosic biomass (water hyacinth) with different fungus for enzymatic hydrolysis and bioethanol production resource: advantages, future work and prospects. Acta Scientific Agriculture, 3(5): 89-96.

Chowdhary, P., Saxena, G. \& Bharagava, R.N. (2016). Role of laccase enzyme in bioremediation of industrial wastes and it biotechnological application. In Bharagava, R.N. \& Saxena, G. (eds.) Bioremendiation of Industrial Pollutants. Delhi, India, Write and Print Publication. Pp. 307-331.

Dashtban, M., Schraft, H., Syed, T.A. \& Wensheng, Q. (2010). Fungal biodegradation and enzymatic modification of lignin. International Journal of Biochemistry and Molecular Biology, 1(1): 36-50.

Dheeran, P., Nandhagopal, N., Kumar, S., Jaiswal, Y. K. \& Adhikari, D.K. (2012). A novel thermostable xylanase of Paenibacillus macerans IIPSP3 isolated from the termite gut. Journal of Industrial Microbiology and Biotechnology, 39(6): 851-860. https://doi.org/10.1007/s10295-012-1093-1

Gonzal, G., Colpa, D.I., Habib, M.H.M. \& Fraaije, M. W. (2016). Bacterial enzymes involved in lignin degradation. Journal of Biotechnology, 236: 110119. https://doi.org/10.1016/j.jbiotec.2016.08.011 
Husain, Q. (2006). Potential applications of the oxidoreductive enzymes in the decolorisation and detoxification of textile and other synthetic dyes from polluted water: a review. Critical Reviews in Biotechnology, 26(4): 201-221.

Inagaki, T. \& Matsuura, K. (2018). Extended mutualism between termites and gut microbes: nutritional symbionts contribute to nest hygiene. The Science of Nature, 105: 52.

Jalali, M. (2014). Isolation and identification of gut symbiont bacteria in the termite Anacanthotermes vagans Hagen (Isoptera: Hodotermitidae) and effects of two biopesticide compound on the termite (Master Thesis). Shahid Chamran University of Ahvaz, Iran.

Janusz, G., Pawlik, A., Sulej, J., Świderska-Burek, U., Jarosz-Wilkołazka, A. \& Paszczyński, A. (2017). Lignin degradation: microorganisms, enzymes involved, genomes analysis and evolution. FEMS Microbiology Reviews, 41(6): 941-962.

Kiiskinen, L.L., Ratto, M. \& Kruus, K. (2004). Screening for novel laccase-producing microbes. Journal of Applied Microbiology, 97: 640-646.

Kundu, P., Manna, B., Majumder, S. \& Ghosh, A. (2019). Species-wide metabolic interaction network for understanding natural lignocellulose digestion in termite gut microbiota. Scientific Reports, 9: 16329.

Lai, C. M.T., Chua, H.B., Danquah, M.K. \& Saptoro, A. (2017). Isolation of thermophilic lignin degrading bacteria from oil-palm empty fruit bunch (EFB) compost. IOP Conference Series: Materials Science and Engineering, 206(1): 012016.

Manji, S. \& Ishihara, A. (2004). Screening of tetrachlorodibenzo- $p$-dioxin-degrading fungi capable of producing extracellular peroxidases under various conditions. Applied Microbiology and Biotechnology, 63: 438-444.

Mathews, S.L., Pawlak, J.J. \& Grunden, A.M. (2014). Isolation of Paenibacillus glucanolyticus from pulp mill sources with potential to deconstruct pulping waste. Bioresource Technology, 164(2014): 100105.

Matte'otti, C., Bauwens, J., Brasseur, C., Tarayre, C., Thonart, P., Destain, J., Francis, F., Haubruge, E., De Pauw, E. \& Portetelle, D. (2012). Identification and characterisation of a new xylanase from Grampositive bacteria isolated from termite gut (Reticulitermes santonensis). Protein Expression and Purification, 83(2): 117-127.
Pangallo, D., ImonovicOva, A.S., Chovanova, K. \& Ferianc, P. (2007). Wooden art objects and the museum environment: identification and biodegradative characteristics of isolated microflora. Letters in Applied Microbiology, 45: 87-94.

Shah, T.A., Lee, C.C., Orts, W.J. \& Tabassum, R. (2019). Biological pretreatment of rice straw by ligninolytic Bacillus sp. strains for enhancing biogas production. Environmental Progress \& Sustainable Energy, 38(3): e13036.

Taylor, C.R., Hardiman, E.M., Ahmad, M., Sainsbury, P.D., Norris, P.R. \& Bugg, T.D.H. (2012). Isolation of bacterial strains able to metabolise lignin from screening of environmental samples. Journal of Applied Microbiology, 113: 521-530.

Tian, J., Feng, J., Wang, Y., Lu, J., Mao, L. \& Chu, J. (2020). A newly isolated Cerrena unicolor capable of laccase production and lignin degradation in agricultural wastes. Research Square, 1: 122812. https://doi.org.10.21203/rs.3.rs.

Wong, L.J., H'ng, P.S., Wong, S.Y., Lee, S.H., Lum, W.C., Chai, E.W., Wong, W.Z. \& Chin, K.L. (2014). Termite digestomes as a potential source of symbiotic microbiota for lignocelluloses degradation: a review. Pakistan Journal of Biological Sciences, 17(8): 956-963.

Yadav, S. \& Chandra, R. (2018). Detection and assessment of the phytotoxicity of residual organic pollutants in sediment contaminated with pulp and paper mill effluent. Environmental Monitoring and Assessment, 190: 581.

Yang, C.X., Wang, T., Gao, L.N., Yin, H.J. \& Lü, X. (2017). Isolation, identification and characterisation of lignin-degrading bacteria from Qinling, China. Journal of Applied Microbiology, 123(6): 14471460.

Zainith, S., Purchase, D., Saratale, G.D., Ferreira, L.F. R., Bilal, M. \& Bharagava, R.N. (2019). Isolation and characterisation of lignin-degrading bacterium Bacillus aryabhattai from pulp and paper mill wastewater and evaluation of its lignin-degrading potential. 3 Biotech, 9(3): 92.

Zhou, H., Guo, W., Xu, B., Teng, Z., Tao, D., Lou, Y. \& Gao, Y. (2017). Screening and identification of lignin-degrading bacteria in termite gut and the construction of LiP-expressing recombinant Lactococcus lactis. Microbial Pathogenesis, 112: 63-69. 